
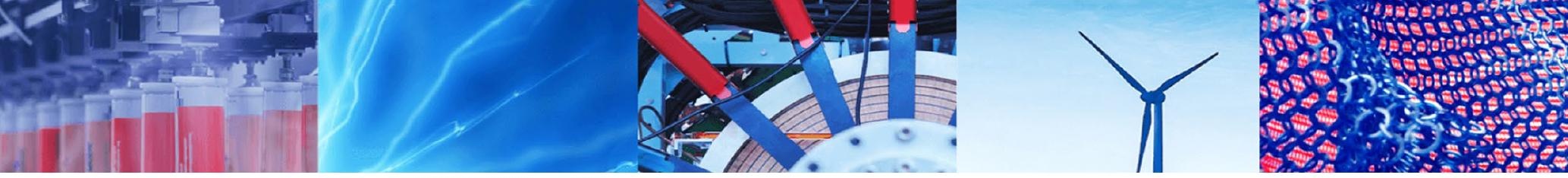

Research Article

\title{
Air pollution tolerance index (APTI) and expected performance index (EPI) of trees in sambalpur town of India
}

\author{
Chandan Sahu, ${ }^{1,2} \cdot$ Sradhanjali Basti ${ }^{1,3} \cdot$ Sanjat Kumar Sahu ${ }^{1}$
}

Received: 23 March 2020 / Accepted: 19 June 2020 / Published online: 3 July 2020

(c) Springer Nature Switzerland AG 2020

\begin{abstract}
Poor disposal of waste and release of pollutants to the environment through urbanization, industrialization and anthropogenic activities have been a serious threat to human health. Therefore, there is a need to evaluate the pollution status of towns through the identification of bio-monitor and bio-indicator trees. Keeping this in view, a work was undertaken to study the Air Pollution Tolerance Index (APTI) and Expected Performance Index (EPI) of trees in Sambalpur town, located in Western flanks of Eastern India during three seasons (monsoon, post-monsoon and pre-monsoon) in 2015-16. The measurements of different biochemical parameters (ascorbic acid: di-chlorophenol indophenol method of Keller and Schwager (Eur J For Pathol 7:338-350, 1977); leaf extract pH: electrometric method of Liu and Ding 2008; relative water content: oven dry method of Prajapati and Tripathi (2008) and total chlorophyll: acetone extraction method of Arnon (Plant Physiol 24:1-15, 1949), and socio-economic characters (plant habit, canopy structure, and type of plant, laminar structure and economic value as per Moore and Chapman (Methods in plant ecology, Blackwell Scientific Publications, Oxford, 1986) and Noor et al. (Environ Geochem Health 1-15, 2014) of selected 21 trees were carried out from five polluted or experimental sites (i.e. Remed, Ainthapali, Dhankauda, Dhanupali and Durgapali) and a non-polluted or control site (i.e. Sambalpur University campus) based on commonness of tree species to all the sites and close proximity to the roads. A total of 45 samples ( 3 trees of each species $\times 5$ leaves from each tree $x$ three replicates per treatment) for every species in each site were analysed as per above standard protocol and methodology. The APTI of the trees in the control site ranged from 8.99 (Butea monosperma) to 31.63 (Peltophorum pterocarpum), while that in the experimental sites it was ranged from 10.47 (Tamarindus indica) to18.04 (Mimusops elengi). In most cases of trees (67.71\%), the APTI values were higher in experimental sites than the selected trees in control site, indicating thereby that the species having higher APTI values had a greater tolerance against air pollution. The categories of various trees, classified on the basis of overall APTI, revealed that in the control site $66.67,19.05$ and $14.28 \%$ of the total trees were in the intermediately tolerant (IT), moderately tolerant (MT) and tolerant (T) categories respectively; whereas in the experimental sites, 42.86, 23.81, 19.05 and $14.28 \%$ of the species were in the intermediately tolerant (IT), moderately tolerant (MT), tolerant (T) and sensitive (S) categories respectively. Finally, based on the EPI scores, the trees found to be fit for plantations are Ficus religiosa, Madhuca indica, Azadirachta indica, Artocarpus heterophyllus, Mangifera indica, Ficus benghalensis and Syzygium cumini, owing to their placement in Best or Excellent category (81-100\%). On the other hand, species like Ziziphus jujuba, Tamarindus indica and Thevetia peruviana can be used as good bio-indicators due to their low EPI scores (31-50\%). This work will be highly useful in formulating the management strategy against rising air pollution issues of the developing urban areas.
\end{abstract}

Keywords Air pollution · Ascorbic acid · Bio-indicators · Leaf extract pH · Relative water content · Socio-economic characters · Total chlorophyll

Chandan Sahu, cks.env@gmail.com; Sradhanjali Basti, shradhasp08@gmail.com; Sanjat Kumar Sahu, sahusanjat@rediffmail.com | ${ }^{1}$ P.G. Department of Environmental Sciences, Sambalpur University, Jyoti Vihar, Burla, Odisha, India. ${ }^{2}$ Gangadhar Meher University, Amruta Vihar, Sambalpur, Odisha, India. ${ }^{3}$ State Pollution Control Board, Bhubaneswar, Odisha, India. 


\section{Introduction}

Plants have been an age-old answer to various kinds of air related problems since time immemorial. With the rise in of population, urbanisation, motorization and industrialization, the composition, concentration and interaction of the primary and the secondary pollutants in the atmosphere get altered. Even though plants are considered a source of pollution in respect of pollen and VOCs, nevertheless these are, to a large extent, regarded as a potent natural cleanser of air today [35]. Being receptors to all types of air pollutants [23], plants have also been reported to undergo several physiological damages and develop diseases like epinasty, chlorosis, necrosis etc. [10,34]. However, the importance of plants can be realized through the fact that they not only purify the air by bio-filtering the pollutants through absorption, impingement and adsorption [11, 49], but also have positive impacts on soil and water quality of the area, besides adding aesthetic value to it [33]. The leaves are the prominent acceptors of the air pollutants, but these show variable behaviour to different type of air pollutants [39]. The same holds true with variability within the same species as well. A few plants show tolerant behaviour to a particular air pollutant, while others have high rate of mortality and hence are sensitive. The tolerant species are suitable for plantation, while the sensitive ones can be used both as bio-indicator as well as biomonitor for providing qualitative and quantitative information of the surrounding respectively $[8,48]$. In either case, plants provide valuable information regarding the quality of air of a particular area [19]. But an integration of various tolerant species can be used for plantation as a defence against the air pollution of the area.

Plants have been reported to be affected indirectly via soil acidification $[7,18,42]$, while the gaseous and particulate pollutants in the atmosphere have direct effect on many morphological, physiological and biochemical characteristics of plants [45]. Although the tolerance of plants to these pollutants have been studied with reference to different aspects such as leaf conductance, glutathione concentration [14,31], peroxidise activity [20], membrane permeability [12] and other biochemical parameters, conflicting results are obtained when $\backslash$ parameters are studied individually even for the same species. A species was found to be tolerant to one parameter while sensitive to another. Based on the above facts, Singh and Rao [43] developed a formula through the aggregation of the four biochemical parameters (relative water content, ascorbic acid, chlorophyll content, and leaf extract $\mathrm{pH}$ ), known as Air Pollution Tolerance Index (APTI). The ascorbic acid is the primary factor of defence, and it acts against any oxidative damage to plants in the water stress condition and also helps in the synthesis of the cell wall, facilitating cell division. It also helps in photosynthesis and is intricately related to the chlorophyll content of the leaf and hence directs the productivity in plants. On the other hand, the leaf $\mathrm{pH}$ governs the photosynthetic efficiency of plants, and the water content of the leaf facilitates transpiration, provides cooling sensation to plants and helps in regaining of vigour during drought conditions. In consequence the leaf water content runs the engine to extract the minerals from the soil through roots of the plants [13]. The APTI is well acclaimed by a wide range of researchers because of the combination of a variety of parameters showing a more reliable result than any analysis based on single parameter [50].

Plants are very often exploited by the people for various purposes. Therefore, mere selection of plants on the basis of their tolerance to air pollutants and subsequent recommendation for plantation may lead to failure in management of these plants and their sustenance. A more logical formulation was drawn by a group of researchers combining the biochemical parameters (as for APTI) with relevant biological and socio-economic characters of a plant species, which is otherwise called Expected Performance Index (EPI) $[5,27,30,32,37,47]$. This index thereafter acted as an ideal and more reliable tool for recommendation of plant species for landscape activities today.

Based on the above facts, a work was undertaken to identify the tolerance of trees to air pollution, taking into account Air Pollution Tolerance Index (APTI) and Expected Performance Index (EPI) of trees in Sambalpur town and to advocate their usefulness for pollution indication and plantation. This work will not only underline the complex linkages between air pollution intensity and the roles played by different trees but also simulate the real situations of most of the towns of the world, especially located in developing and less developed countries.

\section{Materials and methods}

\subsection{Geographical location of the area and sampling}

The urban area taken for the present study is a major town namely, Sambalpur. It is the headquarters town of Sambalpur district, located in the Western flanks of Odisha State in Eastern India. The town is geographically located between $21^{\circ} 27^{\prime} \mathrm{N} ; 84^{\circ} 01^{\prime} \mathrm{E}$ and $21^{\circ} 29^{\prime} \mathrm{N} ; 83^{\circ}$ $55^{\prime} \mathrm{E}$ and situated at an altitude of $145 \mathrm{~m}$ above MSL. The study area experienced a very hot summer $\left(46^{\circ} \mathrm{C}\right)$ and a cold winter $\left(8^{\circ} \mathrm{C}\right)$ and received an annual rainfall of $1527 \mathrm{~mm}$ during the period under report (2015-2016). 
The relative humidity of the area ranged from $30 \%$ (premonsoon) to $75 \%$ (monsoon).

The biological analysis of trees was carried out from five strategic locations inside the Sambalpur town which served as the polluted (or experimental) sites, i.e., Remed (210 30'09" N; 830 56' 35" E), Ainthapali (210 29' 39" N; $\left.83059^{\prime} 14^{\prime \prime} \mathrm{E}\right)$, Dhankauda (210 29' 01" N; 830 59' 17" E), Dhanupali (210 27' 40" N; 830 59' 16" E) and Durgapali (210 29' 08" N; 830 57' 31" E). A non-polluted (or control) site, named Sambalpur University campus (200 $28^{\prime} \mathrm{N} ; 85053^{\prime} \mathrm{E}$ ), was also taken for comparison, which is around $20 \mathrm{~km}$ away from the town and is free from any kind of pollution. This is based on the results of the previous study on ambient air quality and air pollution index carried out during the same period and published elsewhere [38].

Prior to biological analysis of trees for computing APTI and EPI, a survey of local species was made in and around the town, and it was authenticated from the existing literature, supported with the data obtained from the Forest Department, Sambalpur Range Division. The outcome of the survey resulted in the selection of 21 tree species basing on the commonness to all the sites. In all the sites, trees in close proximity to the roads and exposed to traffic were selected for the study. The biological analysis was carried out in three seasons, namely, monsoon (August), post-monsoon (November) and pre-monsoon (April) during 2015 and 2016. The same selected trees were used for sampling to generate authentic data and maintain uniformity during the period under analysis. With the help of a manual of sampling techniques for forest survey [6], five exposed leaves in triplicates were carefully cut (at the base of their petiole at a height of $1.96 \mathrm{~m}$ from the ground surface) from three trees of each species and immediately transported to laboratory in a heat proof container for analysis. A total of 45 samples ( 3 trees of each species $\times 5$ leaves from each tree $\times 3$ replicas per treatment) for every species in each site were analysed during the seasonal studies.

Soil samples at $0-10 \mathrm{~cm}$ depth, as a representative of top soil, were also collected in triplicates from both the sites (control and experimental), using a soil-core sampler and transported to the laboratory in zip-lock plastic packets for the analysis of soil $\mathrm{pH}$ and soil moisture. The soil temperature was measured on the spot using a soil thermometer. Soil $\mathrm{pH}$ was measured by the help of a digital $\mathrm{pH}$ meter using soil: double distilled water in the ratio 1 : $5(\mathrm{w} / \mathrm{v})$ and soil moisture was measured by the standard oven dry procedure and expressed in percentage [40]. The meteorological data was obtained from the nearest Automatic Weather Monitoring Station located at Chakuli Agricultural Farm, Chakuli (aerial distance $10 \mathrm{~km}$ from the study area).

\subsection{Biochemical analysis of the leaf samples and formulation of APTI and EPI}

Relative Water Content (R) of the leaf was measured by taking the fresh weight $\left(W_{f}\right)$, dry weight $\left(W_{d}\right)$ after overnight immersion in distilled water and turgid weight $\left(\mathrm{W}_{t}\right)$ after drying in hot air oven at $105^{\circ} \mathrm{C}$ for $2 \mathrm{~h}$ and using the formula of Prajapati and Tripathi [32] as detailed below:

$R(\%)=\left[\left(W_{f}-W_{d}\right) /\left(W_{t}-W_{d}\right)\right] \times 100$

Leaf Extract $\mathrm{pH}(\mathrm{P})$ was measured electrometrically taking fresh leaf extracts in the ratio 1:5 $(\mathrm{w} / \mathrm{v})$ with deionised water [22].

Ascorbic Acid Content (A) of the leaf sample was measured spectrophotometrically by DCPIP (2,6 - dichlorophenol indophenol) method at $540 \mathrm{~nm}$ and expressed in $\mathrm{mg} / \mathrm{g}$ [17].

Total Chlorophyll ( $\mathrm{T}$ ) was extracted with $80 \%$ acetone and determined spectrophotometrically, following the procedure of Arnon [3], and calculated as per the formula given below:

$\mathrm{T}(\mathrm{mg} / \mathrm{g})=20.2(\mathrm{OD}$ at 645$)+8.02(\mathrm{OD}$ at 663$)$

Based on the analyses of the above bio-chemical parameters, Air Pollution Tolerance Index (APTI) was calculated, using the formula as proposed by Singh and Rao [43]:

$A P T I=\frac{[A(T+P)+R]}{10}$

Further, the APTI values of the trees were used to classify the trees according to Thakar and Mishra [46] which are as follows:

1. Tolerant $(\mathrm{T})$ : $\mathrm{APTI}>$ mean $\mathrm{APTI}+\mathrm{SD}^{*}$

2. Moderately tolerant (MT): mean $\mathrm{APTI}<\mathrm{APTI}<$ mean APTI + SD

3. Intermediate tolerant (IT): mean APTI$\mathrm{SD}<\mathrm{APTI}<$ mean APTI

4. Sensitive (S): APTI < mean APTI-SD

*SD = Standard Deviation, the mean APTI values have been calculated taking the average APTI values of all trees of a particular site.

The socio-economic characters and biological parameters like plant habit, canopy structure, and type of plant, laminar structure and economic value were measured qualitatively as per Moore and Chapman [28]. Expected Performance Index (EPI) was determined by combining the APTI values of the respective tree species with their socio-economic characters and biological parameters, conforming to the grading criteria of Noor et al. [29] as 
shown in the Table 1 and formula developed thereof by Noor et al. [29]:

Expected Performance Index $(E P I)=\frac{\text { No. of }{ }^{\prime}+^{\prime} \text { obtained }}{\text { Total no. of }{ }^{\prime}+^{\prime}} \times 100$

On the basis of EPI score, trees were classified under their respective categories [29] as shown in the Table 2.

The sampling relating to number of leaves, trees, replicates per treatment was carried out following the methods of Chacko [6]. Statistical tests (descriptive, Pearson's correlation coefficient, regression equation, Box-plot diagrams and Two- way ANOVA) relating to bio-socioeconomic parameters of leaves for computing APTI and $\mathrm{EPI}$, and environmental parameters were carried out following the methods of Snedecor and Cochran [44] using SPSS 16.0 software. All the statistical tests were performed at $\mathrm{a}=0.05$ level.

Table 1 Grading Criteria of plants for EPI based on APTI and Socioeconomic characters [29]

\begin{tabular}{|c|c|c|c|}
\hline $\begin{array}{l}\text { Characteristics } \\
\text { assessed (for } \\
\text { grading) }\end{array}$ & $\begin{array}{l}\text { Assessment } \\
\text { hierarchy }\end{array}$ & Category & Grades allocated \\
\hline \multicolumn{4}{|l|}{ Tolerance } \\
\hline \multirow[t]{7}{*}{ APTI } & $<7$ & & - \\
\hline & $7-9$ & & + \\
\hline & $9-11$ & & ++ \\
\hline & $11-13$ & & +++ \\
\hline & $13-15$ & & ++++ \\
\hline & $15-17$ & & ++++ \\
\hline & $17-19$ & & ++++++ \\
\hline \multicolumn{4}{|c|}{ Morphological and economic features } \\
\hline \multirow[t]{3}{*}{ Habit } & Tree & Small & - \\
\hline & & Medium & + \\
\hline & & Large & ++ \\
\hline \multirow[t]{3}{*}{ Canopy } & $\begin{array}{l}\text { Globular/irregu- } \\
\text { lar }\end{array}$ & & - \\
\hline & Spread crown & & + \\
\hline & Dense canopy & & ++ \\
\hline \multirow[t]{2}{*}{ Habit } & Deciduous & & - \\
\hline & Evergreen & & + \\
\hline \multirow[t]{7}{*}{ Leaf Lamina } & Size & Small & - \\
\hline & & Medium & + \\
\hline & & Large & ++ \\
\hline & Texture & Glabrous & - \\
\hline & & Pubescent & + \\
\hline & Hardiness & Soft & - \\
\hline & & Hard & + \\
\hline \multirow[t]{3}{*}{ Economic value } & Frequency & Uses $<3$ & - \\
\hline & & Uses 3-4 & + \\
\hline & & Uses $>4$ & ++ \\
\hline
\end{tabular}

Maximum number of ' + ' for a single species can be 16
Table 2 Assessment category of plants on the basis of their EPI score

\begin{tabular}{lll}
\hline Grading & Percent score & Categories \\
\hline 0 & $\leq 30$ & Not recommended (NR) \\
1 & $31-40$ & Very poor (VP) \\
2 & $41-50$ & Poor (P) \\
3 & $51-60$ & Moderate (M) \\
4 & $61-70$ & Good (G) \\
5 & $71-80$ & Very good (VG) \\
6 & $81-90$ & Excellent (E) \\
7 & $91-100$ & Best (B) \\
\hline
\end{tabular}

\section{Results and discussion}

\subsection{Results}

Table 3 depicts the average environmental data of Sambalpur town in India during 2015-16. From the table it is evident that the air temperature was $25 \pm 0.72^{\circ} \mathrm{C}$ in the monsoon, $23 \pm 0.37^{\circ} \mathrm{C}$ in the post-monsoon and $25.7 \pm 0.93^{\circ} \mathrm{C}$ in the pre-monsoon, while the relative humidity was $46.7 \pm 2.46,44 \pm 1.98$ and $43.6 \pm 2.13 \%$ in the respective seasons. The various soil parameters like soil $\mathrm{pH}$, soil moisture and soil temperature were respectively $6.45 \pm 0.70$, $10.59 \pm 2.60 \%$ and $28.47 \pm 0.56^{\circ} \mathrm{C}$ in monsoon; $8.29 \pm 0.73$, $6.24 \pm 4.58 \%$ and $22.53 \pm 1.92{ }^{\circ} \mathrm{C}$ during post-monsoon and $8.53 \pm 0.85,3.1 \pm 1.16 \%$ and $34.2 \pm 2.81^{\circ} \mathrm{C}$ in the premonsoon. Significant differences were also observed when comparison was made between the values of different environmental parameters with respect to their seasonal variations ( $\mathrm{t} \geq 2.01, p<0.05)$.

Table 4 provides the correlation among various environmental parameters and biochemical parameters of the leaves of various tree species in control and experimental sites. From the table it is evident that the relative humidity and the soil moisture showed significant negative correlations with ascorbic acid content $(r \geq-0.729, p<0.05)$ and leaf extract $\mathrm{pH}(r \geq-0.778, p<0.05)$, whereas significant positive correlations were found in respect of relative water content $(r \geq+0.836, p<0.05)$, total chlorophyll content $(r \geq+0.958, p<0.05)$ and APTI value $(r \geq+0.788$, $p<0.05)$. Soil pH exhibited significant positive correlations with ascorbic acid and leaf extract $\mathrm{pH}(r \geq+0.808, p<0.05)$ and significant negative correlations with relative water content, total chlorophyll and the APTI value $(r \geq-0.779$, $p<0.05)$. However, all the biochemical parameters did not show any significant correlation with the air temperature as well as soil temperature $(p>0.05)$. Based on the above findings of the correlation coefficient $(p<0.05)$, regression models $(y=a x+b)$ were computed between different environmental parameters (relative humidity, 
Table 3 Average Environmental data of Sambalpur town in India during 2015-16

\begin{tabular}{llllll}
\hline & Air Temp. $\left({ }^{\circ} \mathrm{C}\right)$ & $\mathrm{RH}(\%)$ & Soil pH & Soil Moist. $(\%)$ & Soil Temp. $\left({ }^{\circ} \mathrm{C}\right)$ \\
\hline Monsoon & $25.00 \pm 0.72^{\mathrm{a}}$ & $46.70 \pm 2.46^{\mathrm{a}}$ & $6.45 \pm 0.70^{\mathrm{a}}$ & $10.59 \pm 2.60^{\mathrm{a}}$ & $28.47 \pm 0.56^{\mathrm{a}}$ \\
Post Monsoon & $23.00 \pm 0.37^{\mathrm{b}}$ & $44.00 \pm 1.98^{\mathrm{b}}$ & $8.29 \pm 0.73^{\mathrm{b}}$ & $6.24 \pm 4.58^{\mathrm{b}}$ & $22.53 \pm 1.92^{\mathrm{b}}$ \\
Pre Monsoon & $25.70 \pm 0.93^{\mathrm{c}}$ & $43.60 \pm 2.13^{\mathrm{c}}$ & $8.53 \pm 0.85^{\mathrm{c}}$ & $3.10 \pm 1.16^{\mathrm{c}}$ & $34.20 \pm 2.81^{\mathrm{c}}$ \\
\hline
\end{tabular}

$\mathrm{n}=107$ (monsoon), $\mathrm{n}=151$ (post monsoon), $\mathrm{n}=107$ (pre monsoon); Data in the same column with different alphabets in the superscript are significantly different $(p<0.05)$
Table 4 Correlations among various environmental parameters and biochemical parameters of the leaves of trees in control and experimental sites of Sambalpur, India

\begin{tabular}{lrrrrr}
\hline & Air Temp & RH & Soil pH & Soil Moist & Soil Temp \\
\hline A & -0.560 & $-0.904^{*}$ & $0.909^{*}$ & $-0.729^{*}$ & -0.328 \\
P & -0.714 & $-0.801^{*}$ & $0.808^{*}$ & $-0.778^{*}$ & -0.509 \\
R & -0.416 & $0.836^{*}$ & $-0.829^{*}$ & $0.964^{*}$ & -0.636 \\
T & -0.139 & $0.958^{*}$ & $-0.954^{*}$ & $0.999^{*}$ & -0.389 \\
APTI & -0.490 & $0.788^{*}$ & $-0.779^{*}$ & $0.939^{*}$ & -0.698 \\
\hline
\end{tabular}

$\mathrm{n}=45,{ }^{*} p<0.05$

$\mathrm{A}=$ Ascorbic acid content, $\mathrm{P}=$ Leaf extract $\mathrm{pH}, \mathrm{R}=$ Relative water content, $\mathrm{T}=$ Total Chlorophyll content, $\mathrm{APTI}=$ Air Pollution Tolerance Index, $\mathrm{RH}=$ Relative Humidity

soil $\mathrm{pH}$ and soil moisture) and the overall APTI, which are respectively $y=0.357 x-1.95, y=-0.524 x+18.12$ and $y=0.191 x+12.78$.

Table 5 gives the results of biochemical analysis (ascorbic acid, leaf extract $\mathrm{pH}$, and relative water content and total chlorophyll), APTI and response category of various trees in control and experimental sites during the period under report. The ascorbic acid ranged from 3.04 (Madhuca indica) to $24.90 \mathrm{mg} / \mathrm{g}$ ( $P$. petrocarpum) in the control and 3.47 (T. indica) to $10.55 \mathrm{mg} / \mathrm{g}$ (Madhuca indica) in the experimental sites. Similarly, the leaf extract $\mathrm{pH}$ ranged from 3.24 (T. indica) to 7.66 (F. religiosa) and 3.29 (T. indica) to 7.70 ( $F$. benghalensis) in the control and experimental sites respectively. The relative water content in the control and experimental sites were found to range from a minimum of 53.91 (A. heterophyllus) and $56.26 \%$ ( $Z$. jujuba) to a maximum of 89.81 (F. religiosa) and $91.75 \%$ (F. benghalensis) respectively. The mean concentration of the total chlorophyll content in the control site varied between 0.69 (G. arborea) and 3.59 ( $T$. indica) $\mathrm{mg} / \mathrm{g}$, while that in the experimental sites varied between and 2.12 ( $T$. peruviana) and 4.32 (T. indica) $\mathrm{mg} / \mathrm{g}$. Similarly, the APTI of the trees in the control site ranged from a minimum of 8.99 (B. monosperma) to a maximum of 31.63 ( $P$. pterocarpum), while that in the experimental sites ranged from a minimum of 10.47 ( $T$. indica) to a maximum of 18.04 ( $M$. elengi). A comparison of the APTI values of different trees in control and experimental sites is presented in Fig. 1. It is observed that in most cases, the APTI values are higher in experimental sites than in their counterparts in the control site. However, the t-test computed between the control and experimental sites for individual biochemical parameters as well as overall APTI did not show any significant difference ( $t \leq 1.71, p>0.05)$, excepting total chlorophyll content $(\mathrm{t}=5.15, p<0.05)$.

The categories of various trees on the basis of overall APTI in the control and experimental sites reflects that in the control site trees on an average $66.67,19.05$ and $14.28 \%$ of the total number, were found to be in the intermediately tolerant (IT), moderately tolerant (MT) and tolerant $(T)$ categories, respectively. On the other hand, in the experimental sites trees on an average 42.86, 23.81, 19.05 and $14.28 \%$ of the total number were found to be in the intermediately tolerant (IT), moderately tolerant (MT), tolerant $(\mathrm{T})$ and sensitive $(\mathrm{S})$ categories respectively.

The correlation matrices were worked out among various analysed parameters for control and experimental sites and they are presented in Tables 6 and 7 respectively. The ' $r$ ' value marked with an asterisk $\left({ }^{*}\right)$ represents significant correlation among the two parameters at 0.05 level of significance. In the control site, APTI showed significant positive correlations with ascorbic acid content and total chlorophyll content $(r \geq+0.380, p<0.05)$, while the leaf extract $\mathrm{pH}$ showed significant negative correlation with the total chlorophyll content $(r=-0.481, p<0.05)$. The experimental site witnessed a significant negative correlation between the leaf extract $\mathrm{pH}$ and total chlorophyll content $(r=-0.524, p<0.05)$ and a significant positive correlation between APTI and relative water content $(r=+0.595, p<0.05)$ as well as APTI and the ascorbic acid content $(r=+0.906, p<0.05)$.

The data for each biochemical parameter was subjected to a two way ANOVA test in both control and experimental sites with respect to species and seasons, and the findings are presented in Table 8. There was no significant variation with respect to species and seasons both in control and experimental sites, for the ascorbic acid and the overall APTI $\left(F_{1} \leq 1.79, F_{2} \leq 2.36, p>0.05\right)$. On the other hand, significant variation was found with respect to species and seasons, both in control and experimental sites for leaf extract $\mathrm{pH}$ and the total chlorophyll content $\left(\mathrm{F}_{1} \geq 1.88\right.$, $\left.\mathrm{F}_{2} \geq 3.52, p<0.05\right)$. The relative water content showed a significant variation with respect to seasons only $\left(F_{2}=4.85\right.$, 
Table 5 Biochemical parameters and Air Pollution Tolerance Index and response category of various tree species in control and experimental sites of Sambalpur, India during 2015-16

\begin{tabular}{|c|c|c|c|c|c|c|c|}
\hline SI. No & Sites & $A(\mathrm{mg} / \mathrm{g})$ & $P$ & $\mathrm{R}(\%)$ & $\mathrm{T}(\mathrm{mg} / \mathrm{g})$ & APTI & Category \\
\hline \multirow[t]{2}{*}{1} & $C$ & $5.71 \pm 3.90$ & $6.13 \pm 0.33$ & $68.88 \pm 20.44$ & $1.56 \pm 0.69$ & $11.40 \pm 1.49$ & IT \\
\hline & $\mathrm{E}$ & $5.32 \pm 2.96$ & $5.45 \pm 0.34$ & $75.19 \pm 14.75$ & $4.54 \pm 1.38$ & $12.47 \pm 3.86$ & IT \\
\hline \multirow[t]{2}{*}{2} & $C$ & $5.52 \pm 2.11$ & $6.69 \pm 0.41$ & $72.74 \pm 27.27$ & $0.88 \pm 0.23$ & $11.45 \pm 8.51$ & IT \\
\hline & $E$ & $5.61 \pm 2.91$ & $6.79 \pm 0.41$ & $70.69 \pm 3.26$ & $2.29 \pm 1.20$ & $12.00 \pm 2.60$ & IT \\
\hline \multirow[t]{2}{*}{3} & $C$ & $4.68 \pm 2.98$ & $6.61 \pm 0.40$ & $73.11 \pm 5.57$ & $0.69 \pm 0.22$ & $10.70 \pm 2.64$ & IT \\
\hline & $E$ & $5.77 \pm 4.57$ & $6.32 \pm 0.32$ & $72.08 \pm 2.09$ & $2.71 \pm 1.06$ & $11.93 \pm 3.52$ & IT \\
\hline \multirow[t]{2}{*}{4} & $\mathrm{C}$ & $3.44 \pm 2.99$ & $6.67 \pm 0.12$ & $63.37 \pm 9.00$ & $1.26 \pm 0.55$ & $8.99 \pm 2.68$ & IT \\
\hline & $\mathrm{E}$ & $4.77 \pm 0.73$ & $6.62 \pm 0.24$ & $65.52 \pm 6.44$ & $2.82 \pm 1.85$ & $11.15 \pm 2.08$ & $S$ \\
\hline \multirow[t]{2}{*}{5} & $\mathrm{C}$ & $8.53 \pm 3.22$ & $6.19 \pm 0.32$ & $67.59 \pm 1.49$ & $1.72 \pm 1.20$ & $12.97 \pm 8.89$ & IT \\
\hline & $\mathrm{E}$ & $6.87 \pm 2.55$ & $6.53 \pm 0.36$ & $68.36 \pm 9.53$ & $2.46 \pm 1.45$ & $12.60 \pm 1.58$ & IT \\
\hline \multirow[t]{2}{*}{6} & $\mathrm{C}$ & $9.36 \pm 6.11$ & $6.75 \pm 0.24$ & $79.87 \pm 8.47$ & $1.91 \pm 0.96$ & $15.98 \pm 6.99$ & MT \\
\hline & $\mathrm{E}$ & $9.94 \pm 4.61$ & $6.52 \pm 0.48$ & $84.75 \pm 2.49$ & $3.07 \pm 1.17$ & $17.94 \pm 5.31$ & $\mathrm{~T}$ \\
\hline \multirow[t]{2}{*}{7} & $C$ & $4.21 \pm 1.89$ & $7.05 \pm 0.37$ & $75.32 \pm 5.30$ & $1.30 \pm 0.21$ & $10.96 \pm 1.75$ & IT \\
\hline & $E$ & $7.64 \pm 5.02$ & $6.32 \pm 0.43$ & $86.36 \pm 2.59$ & $2.72 \pm 1.63$ & $15.08 \pm 2.81$ & MT \\
\hline \multirow[t]{2}{*}{8} & C & $7.87 \pm 2.17$ & $5.78 \pm 0.08$ & $84.62 \pm 3.16$ & $2.00 \pm 0.33$ & $14.53 \pm 1.21$ & MT \\
\hline & $E$ & $10.28 \pm 2.11$ & $6.04 \pm 0.15$ & $86.14 \pm 6.41$ & $3.96 \pm 1.43$ & $18.04 \pm 2.63$ & $\mathrm{~T}$ \\
\hline \multirow[t]{2}{*}{9} & $\mathrm{C}$ & $11.11 \pm 7.45$ & $7.66 \pm 1.61$ & $89.81 \pm 1.72$ & $1.60 \pm 0.78$ & $20.17 \pm 8.31$ & $\mathrm{~T}$ \\
\hline & $\mathrm{E}$ & $6.14 \pm 1.36$ & $7.58 \pm 1.14$ & $90.54 \pm 2.17$ & $2.81 \pm 1.83$ & $15.75 \pm 1.69$ & MT \\
\hline \multirow[t]{2}{*}{10} & $\mathrm{C}$ & $5.04 \pm 4.21$ & $6.65 \pm 0.64$ & $56.86 \pm 18.08$ & $1.88 \pm 0.45$ & $9.76 \pm 1.20$ & IT \\
\hline & $E$ & $5.82 \pm 1.64$ & $6.33 \pm 0.27$ & $56.26 \pm 7.80$ & $2.96 \pm 1.64$ & $10.98 \pm 1.58$ & $S$ \\
\hline \multirow[t]{2}{*}{11} & $C$ & $4.88 \pm 3.36$ & $6.67 \pm 0.13$ & $53.91 \pm 24.29$ & $3.01 \pm 1.33$ & $10.07 \pm 4.72$ & IT \\
\hline & $E$ & $5.21 \pm 1.17$ & $6.60 \pm 0.29$ & $75.13 \pm 8.82$ & $3.12 \pm 1.50$ & $12.50 \pm 2.02$ & IT \\
\hline \multirow[t]{2}{*}{12} & $C$ & $4.78 \pm 3.02$ & $6.87 \pm 0.33$ & $68.64 \pm 5.54$ & $2.05 \pm 0.90$ & $11.22 \pm 3.20$ & IT \\
\hline & $E$ & $5.13 \pm 2.30$ & $6.86 \pm 0.26$ & $73.02 \pm 8.86$ & $2.61 \pm 1.57$ & $12.20 \pm 2.84$ & IT \\
\hline \multirow[t]{2}{*}{13} & $C$ & $10.62 \pm 8.28$ & $5.62 \pm 0.16$ & $86.45 \pm 10.98$ & $2.48 \pm 0.65$ & $17.36 \pm 6.13$ & MT \\
\hline & $\mathrm{E}$ & $4.96 \pm 0.50$ & $5.54 \pm 0.35$ & $93.73 \pm 1.00$ & $2.88 \pm 1.47$ & $13.47 \pm 0.78$ & IT \\
\hline \multirow[t]{2}{*}{14} & $\mathrm{C}$ & $4.62 \pm 1.97$ & $7.28 \pm 0.37$ & $84.11 \pm 18.43$ & $2.04 \pm 0.49$ & $12.75 \pm 2.88$ & IT \\
\hline & $\mathrm{E}$ & $4.46 \pm 3.26$ & $7.70 \pm 0.72$ & $91.75 \pm 0.85$ & $2.87 \pm 1.54$ & $13.51 \pm 2.82$ & IT \\
\hline \multirow[t]{2}{*}{15} & $C$ & $10.59 \pm 6.29$ & $6.75 \pm 0.42$ & $68.06 \pm 16.89$ & $1.89 \pm 1.02$ & $15.53 \pm 7.87$ & MT \\
\hline & $E$ & $8.43 \pm 4.31$ & $6.52 \pm 0.33$ & $78.19 \pm 4.20$ & $2.12 \pm 0.96$ & $15.04 \pm 3.75$ & MT \\
\hline \multirow[t]{2}{*}{16} & $\mathrm{C}$ & $4.51 \pm 3.35$ & $6.23 \pm 0.26$ & $81.63 \pm 11.20$ & $2.09 \pm 1.02$ & $11.82 \pm 4.79$ & IT \\
\hline & $\mathrm{E}$ & $8.48 \pm 5.16$ & $6.09 \pm 0.59$ & $85.46 \pm 4.52$ & $3.08 \pm 2.06$ & $15.74 \pm 2.78$ & MT \\
\hline \multirow[t]{2}{*}{17} & $C$ & $24.90 \pm 20.61$ & $6.34 \pm 0.31$ & $62.52 \pm 6.07$ & $3.33 \pm 1.24$ & $31.63 \pm 22.90$ & $\mathrm{~T}$ \\
\hline & $E$ & $9.27 \pm 2.16$ & $6.28 \pm 0.43$ & $71.06 \pm 1.78$ & $3.64 \pm 1.32$ & $16.31 \pm 3.43$ & MT \\
\hline \multirow[t]{2}{*}{18} & $\mathrm{C}$ & $13.85 \pm 7.33$ & $6.20 \pm 0.27$ & $79.53 \pm 9.25$ & $2.31 \pm 0.48$ & $20.23 \pm 14.90$ & $\mathrm{~T}$ \\
\hline & $\mathrm{E}$ & $9.55 \pm 3.85$ & $6.11 \pm 0.32$ & $90.42 \pm 1.88$ & $3.73 \pm 1.84$ & $17.30 \pm 1.84$ & $\mathrm{~T}$ \\
\hline \multirow[t]{2}{*}{19} & $\mathrm{C}$ & $4.83 \pm 1.89$ & $5.01 \pm 0.50$ & $85.74 \pm 15.49$ & $1.40 \pm 0.95$ & $11.29 \pm 4.24$ & IT \\
\hline & $\mathrm{E}$ & $6.42 \pm 3.51$ & $4.79 \pm 0.34$ & $91.21 \pm 2.80$ & $2.78 \pm 1.62$ & $13.38 \pm 1.77$ & IT \\
\hline \multirow[t]{2}{*}{20} & $\mathrm{C}$ & $3.50 \pm 2.17$ & $3.24 \pm 0.09$ & $75.10 \pm 7.40$ & $3.59 \pm 2.58$ & $10.48 \pm 3.04$ & IT \\
\hline & $\mathrm{E}$ & $3.47 \pm 2.23$ & $3.29 \pm 0.31$ & $77.95 \pm 4.22$ & $4.32 \pm 0.53$ & $10.47 \pm 1.31$ & $S$ \\
\hline \multirow[t]{2}{*}{21} & $\mathrm{C}$ & $3.04 \pm 2.30$ & $5.52 \pm 0.56$ & $80.93 \pm 7.38$ & $2.46 \pm 1.12$ & $10.15 \pm 1.97$ & IT \\
\hline & $\mathrm{E}$ & $10.55 \pm 2.81$ & $5.39 \pm 0.47$ & $87.25 \pm 0.94$ & $2.78 \pm 1.89$ & $17.89 \pm 5.20$ & $\mathrm{~T}$ \\
\hline
\end{tabular}

$\mathrm{n}=45$; SI.No.1-Diospyros melanoxylon (Kendu), 2-Pongamia pinnata (Karanja), 3-Gmelina arborea (Gambhari), 4-Butea monosperma (Palas), 5-Tectona grandis (Saguan), 6-Azadirachta indica (Neem), 7-Bombax ceiba (Simili), 8-Mimusops elengi (Baula), 9-Ficus religiosa (Peepal), 10-Ziziphus jujuba (Borokoli), 11-Artocarpus heterophyllus (Panas), 12-Dalbergia latifolia (Sissoo), 13-Mangifera indica (Mango), 14-Ficus benghalensis (Bara), 15-Thevetia peruviana (Kanyara), 16-Aegle marmelos (Bela), 17-Peltophorum pterocarpum (Radhachuda), 18-Polyalthia longifolia (Debdaru), 19-Syzygium cumini (Jamun), 20-Tamarindus indica (Tetel) and 21-Madhuca indica (Mahul); A-Ascorbic acid, P-Leaf extract $\mathrm{pH}, \mathrm{R}$-Relative water content, T-Total chlorophyll content, APTI-Air Pollution Tolerance Index, C-Control, E-Experimental, IT-Intermediately Tolerant, MT-Moderately Tolerant, T-Tolerant, S-Sensitive. The names in the brackets are the common names of the tree species 

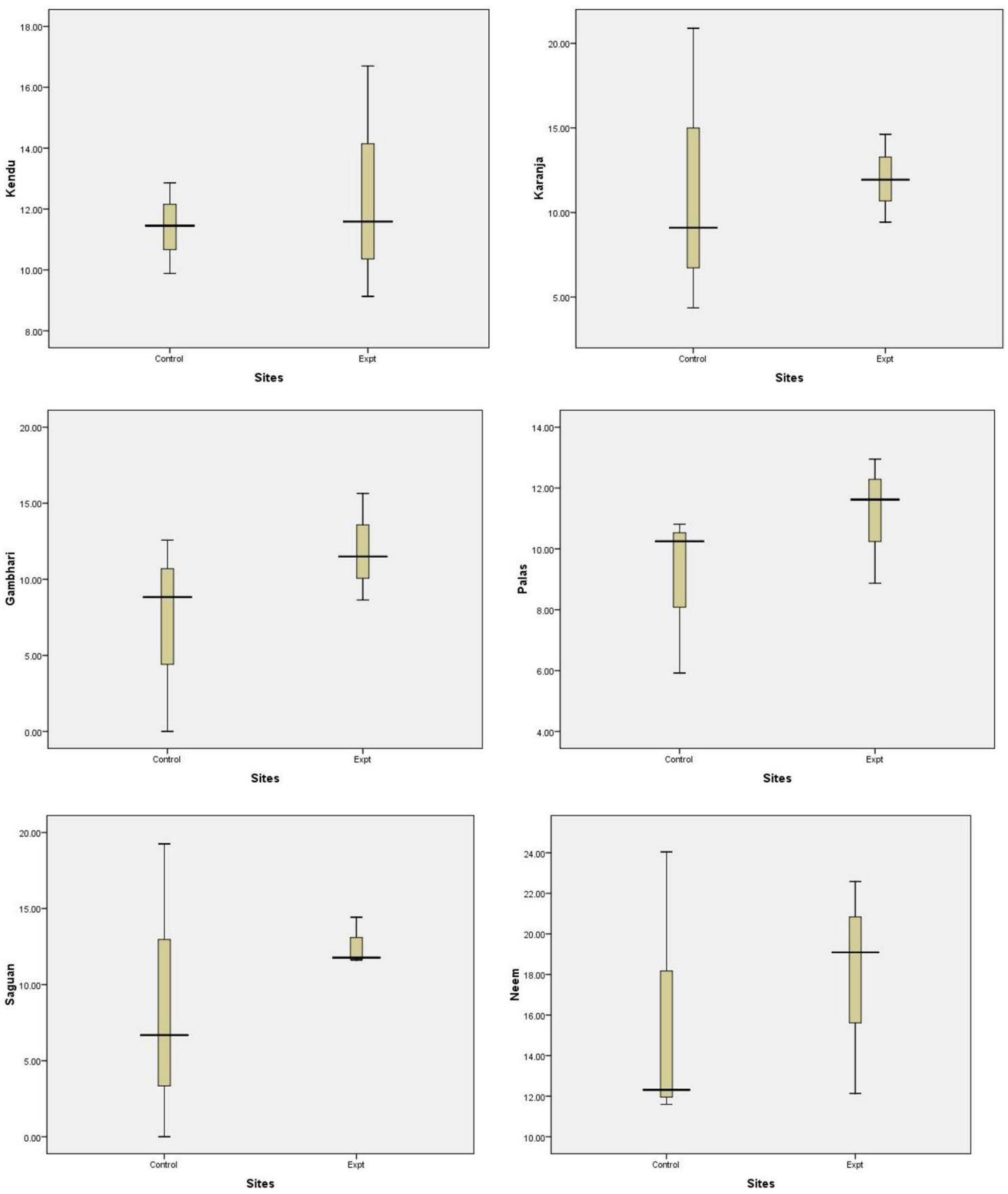

Fig. 1 Box plots showing a comparison of Air Pollution Tolerance Index (APTI) in trees of control and experimental sites of Sambalpur, India during 2015-16. The Y-axis shows the APTI values $(n=45)$

$p<0.05)$ in the control site and species only $\left(\mathrm{F}_{1}=2.63\right.$, $p<0.05)$ in the experimental sites.

Table 9 summarizes the EPI of different tree species in experimental sites located in Sambalpur town during 2015-16. From the table it is evident that, F. religiosa was under best performer category with a total grade score of 15 (93.75\%), while species like Madhuca indica, A. indica, A. heterophyllus, Mangifera indica, F. benghalensis and S. cumini was under very good to excellent performer category with grade scores of 13 or 14 ( $\geq 81 \%$ to $\leq 90 \%)$. On the other hand tree species like $T$. grandis, D. latifolia, $T$. peruviana, T. indica and $Z$. jujuba was under poor to very poor performer category with grade score $\leq 8(<51 \%)$. Other species are in the moderate to very good category owing to a grade score in the range of 51 to $70 \%$. The trend of the EPI scoring of different tree species was 

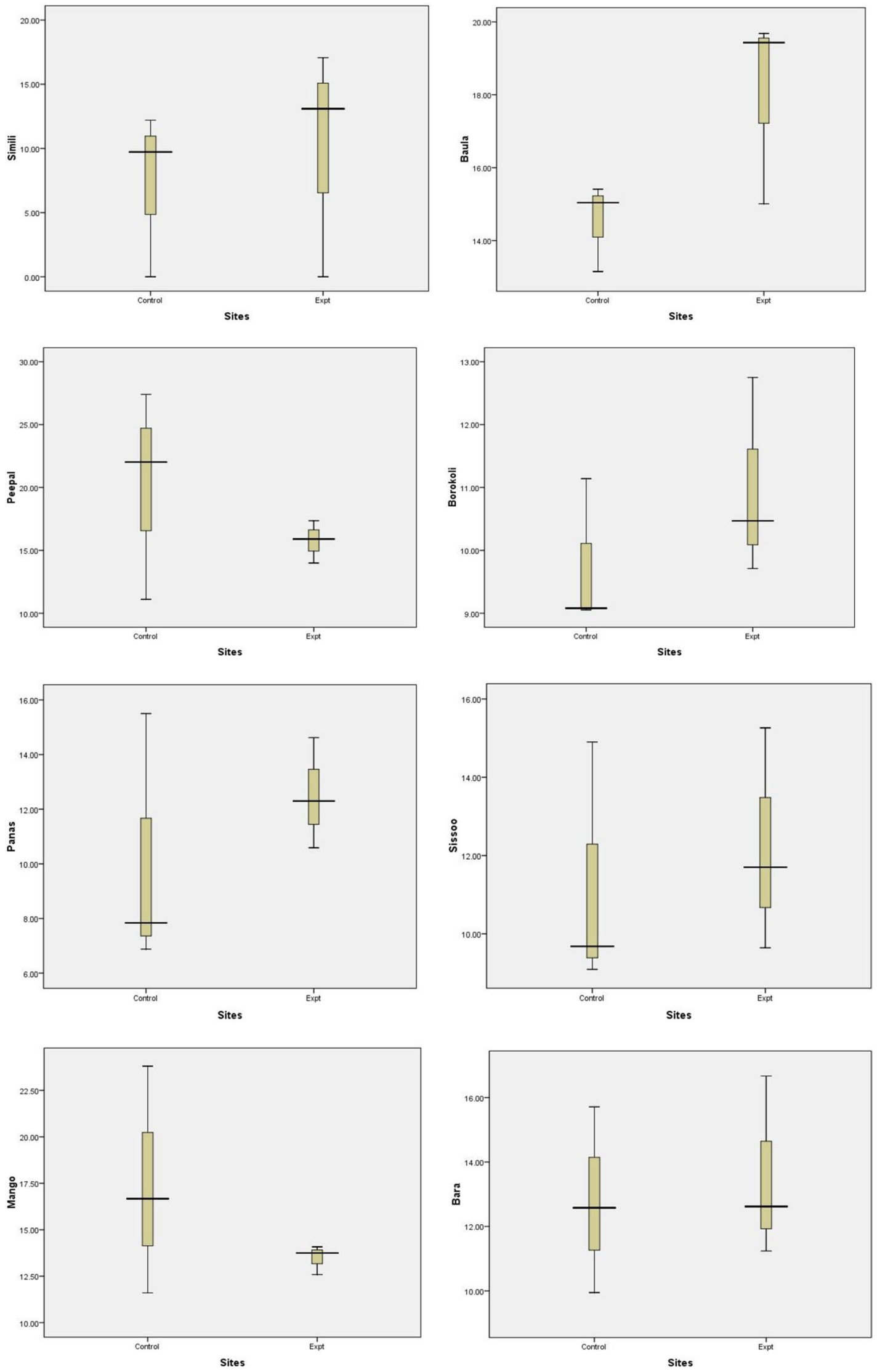

Fig. 1 (continued)

SN Applied Sciences

A SPRINGER NATURE journal 

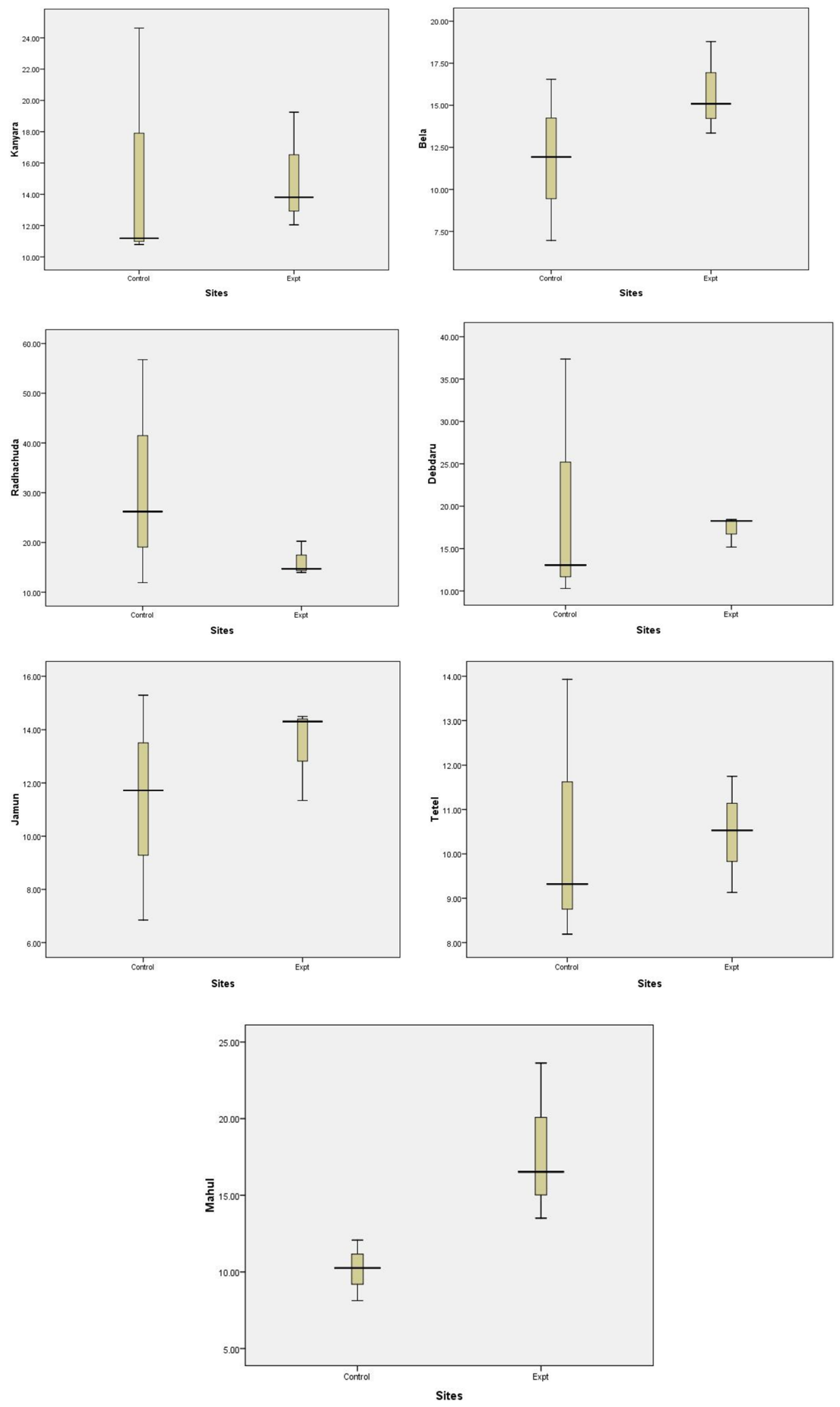

Fig. 1 (continued) 
Table 6 Correlation matrix among various biochemical parameters in control site (Sambalpur University Campus, Sambalpur, India)

\begin{tabular}{llllll}
\hline & APTI & \multicolumn{1}{l}{ R } & A & T & P \\
\hline APTI & 1.000 & & & & \\
R & 0.125 & 1.000 & & & \\
A & $0.978^{*}$ & -0.034 & 1.000 & & \\
T & $0.380^{*}$ & -0.132 & 0.364 & 1.000 & \\
P & 0.140 & -0.143 & 0.136 & $-0.481^{*}$ & 1.000 \\
\hline
\end{tabular}

$\mathrm{n}=45,{ }^{*} p<0.05$

$\mathrm{A}=$ Ascorbic acid content, $\mathrm{P}=$ Leaf extract $\mathrm{pH}, \mathrm{R}=$ Relative water content, $\mathrm{T}=$ Total Chlorophyll content, $\mathrm{APTI}=$ Air Pollution Tolerance Index

Table 7 Correlation matrix among various biochemical parameters in experimental sites of Sambalpur town in India

\begin{tabular}{llllll}
\hline & APTI & R & A & T & P \\
\hline APTI & 1.000 & & & & \\
R & $0.595^{*}$ & 1.000 & & & \\
A & $0.906^{*}$ & 0.280 & 1.000 & & \\
T & 0.091 & 0.079 & 0.027 & 1.000 & \\
P & 0.146 & -0.087 & 0.061 & $-0.524^{*}$ & 1.000 \\
\hline
\end{tabular}

$\mathrm{n}=45,{ }^{*} p<0.05$

in the following order: $F$ religiosa $>$ Madhuca inidca $>A$. indica $=A$. heterophyllus $=$ Mangifera indica $=F$. bengha lensis $=S$. cumini $>$ D. melonoxylon $=B$. ceiba $>$ P. pinnata $=M$. eleng $i=P$. pterocarpum $=P$. longifolia $>$ G. arborea $=B$. monosperma $=A$. marmelos $>T$. grandis $=D$. latifolia $=T$. peruviana $=T$. indica $>Z$. jujuba. Although it was noted that in most occasions, a species with greater tolerance behaviour as per APTI, showed a better EPI scoring, but no generalization can be made on this. This is because of the fact that insignificant positive correlation was obtained between APTI and EPI $(r=0.483, p>0.05)$.

\section{Discussion}

The tolerance behaviour of trees to air pollutants can be best described to assess their potential in remediating the air pollution problem and purifying the local air of an area. The fluctuations in climatic conditions and the response of plants can help mitigate the local or regional air pollution issues. Since the bio-chemical synthesis in plants is also directed by many environmental conditions, an evaluation of the bio-chemical parameters of trees can be of immense help for the determination of their tolerance behaviour. The negative correlations of the soil temperature and air temperature with all the biochemical parameters in the present findings suggest that plants operate well within a range of temperature and any increase or decrease in the temperature can affect their tolerance behaviour [22]. Further, the negative correlations (between relative humidity as well as soil moisture with ascorbic acid and leaf extract $\mathrm{pH}$, and soil $\mathrm{pH}$ with relative water content, total chlorophyll content as well as APTI) and positive correlations (between relative humidity as well as soil moisture with relative water content, total chlorophyll content and APTI; and soil $\mathrm{pH}$ with ascorbic acid as well as leaf extract $\mathrm{pH}$ ) were observed between different environmental parameters and biochemical parameters. These observations were also in line with the results reported by other workers suggesting that fluctuations in environmental conditions like temperature, water content, relative humidity, soil acidification etc. may alter the plants tolerance behaviour $[2,4$, $24,25]$. In the present study, APTI showed definite significant correlations $(p<0.05)$ with environmental parameters
Table 8 Two Way ANOVA among different biochemical parameters of various species and seasons in control and experimental sites of Sambalpur, India

\begin{tabular}{|c|c|c|c|c|c|c|c|c|c|}
\hline & \multirow[t]{2}{*}{ Source of variation } & \multicolumn{4}{|l|}{ Control } & \multicolumn{4}{|c|}{ Experimental } \\
\hline & & SS & $d f$ & MS & F cal & SS & df & MS & $\mathrm{F} \mathrm{cal}$ \\
\hline \multirow[t]{2}{*}{ A } & Between species & 1574.93 & 20 & 78.75 & 1.21 & 280.76 & 20 & 14.04 & 1.37 \\
\hline & Between seasons & 23.57 & 2 & 11.79 & 0.18 & 20.4 & 2 & 10.2 & 1 \\
\hline \multirow[t]{2}{*}{$P$} & Between species & 75.26 & 20 & 3.76 & $1.88^{*}$ & 64.27 & 20 & 3.21 & $4.30^{*}$ \\
\hline & Between seasons & 17.3 & 2 & 8.65 & $4.33^{*}$ & 5.26 & 2 & 2.63 & $3.52^{*}$ \\
\hline \multirow[t]{2}{*}{$\mathrm{R}$} & Between species & $11,372.5$ & 20 & 568.63 & 1.6 & 7473.63 & 20 & 373.68 & $2.63^{*}$ \\
\hline & Between seasons & 3449.32 & 2 & 1724.66 & $4.85^{*}$ & 701.93 & 2 & 350.96 & 2.47 \\
\hline \multirow[t]{2}{*}{$\mathrm{T}$} & Between species & 38.02 & 20 & 1.9 & $2.36^{*}$ & 28.22 & 20 & 1.41 & $5.80^{*}$ \\
\hline & Between seasons & 17.87 & 2 & 8.93 & $11.11^{*}$ & 90.32 & 2 & 45.16 & $185.58^{*}$ \\
\hline \multirow[t]{2}{*}{ APTI } & Between species & 1902.21 & 20 & 95.11 & 1.44 & 402.39 & 20 & 20.12 & 1.79 \\
\hline & Between seasons & 8.29 & 2 & 4.15 & 0.06 & 52.82 & 2 & 26.41 & 2.36 \\
\hline
\end{tabular}

A-Ascorbic acid, P-Leaf extract $\mathrm{pH}, \mathrm{R}$-Relative water content, T-Total chlorophyll content, APTI-Air Pollution Tolerance Index, Critical value between species-1.84, Critical value between seasons-3.23, ${ }^{*} p<0.05$ 


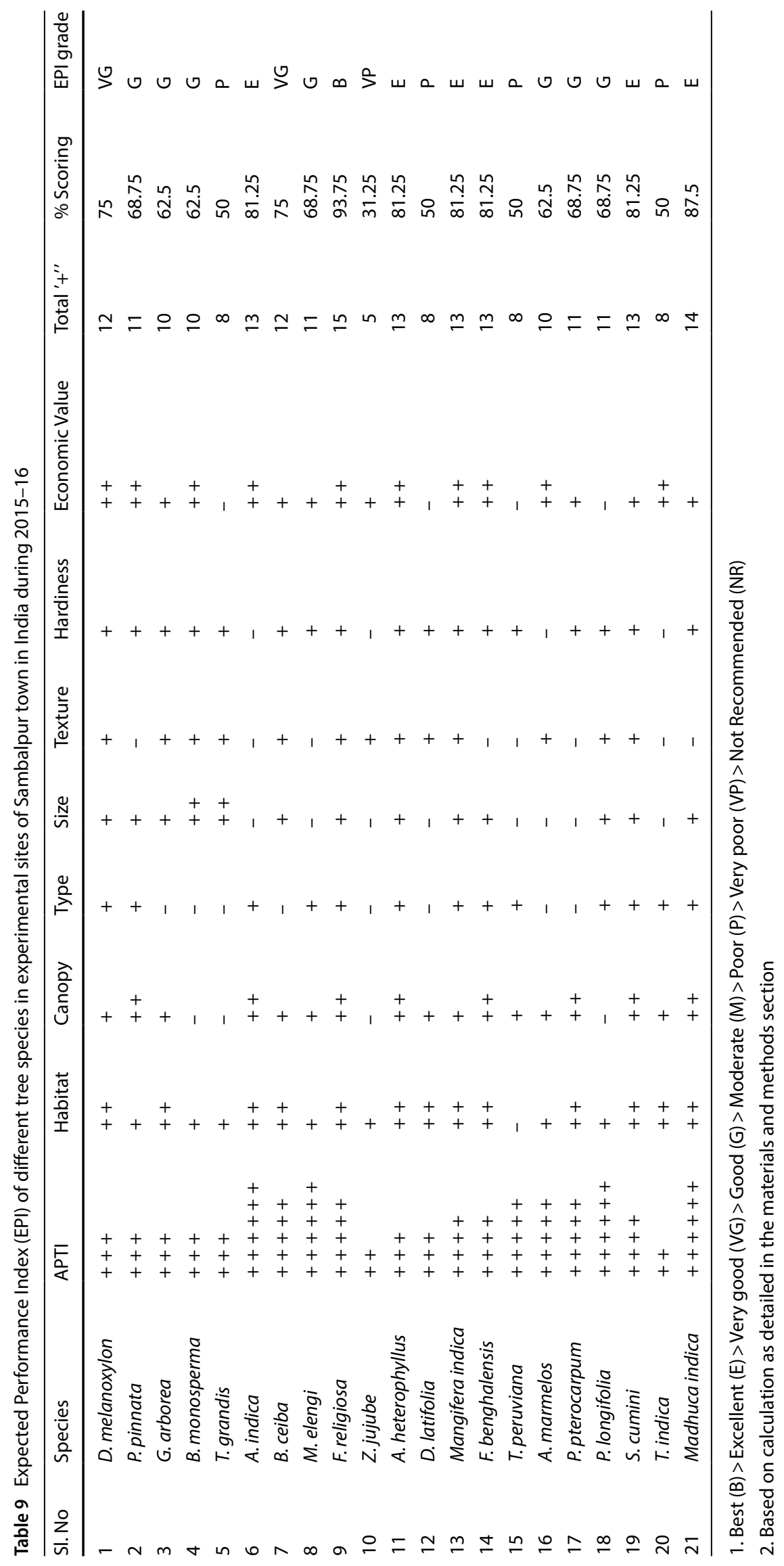


like relative humidity, soil $\mathrm{pH}$ and soil moisture, clearly indicating that regression equations can be used to predict the value of APTI from these environmental parameters. However, with this limited case specific study no generalization can be made at this juncture.

Ascorbic acid in plant leaves has multiple functions to perform through cell wall synthesis, cell division, photosynthetic carbon fixation and acts as a strong reducer protecting the plants against reactive oxygen species (ROS), thereby improving the tolerance ability of the trees against air pollution. The tolerance level in plants increases with increase in ascorbic acid content [21]. The present study revealed that $57.14 \%$ of the sampled tree species have enhanced ascorbic acid content in the experimental sites as compared to their counterparts in the control site. This indicates that trees had developed better tolerance ability when exposed to polluted environment through increased ascorbic acid synthesis. A significant correlation of ascorbic acid with the APTI value in both control and experimental sites support the findings of Agbaire and Esiefarienrhe [1] and Meerabai et al. [26].

The leaf extract $\mathrm{pH}$ is known to impact the ascorbic acid synthesis of trees. Increase in the leaf extract $\mathrm{pH}$ value has been reported to efficiently convert the hexose sugar to ascorbic acid and therefore a high $\mathrm{pH}$ is considered good for the tolerance of trees against air pollution $[15,41]$. In the present study only $23.81 \%$ of trees were found to have high leaf extract $\mathrm{pH}$ in the experimental sites than their counterparts in the control site. This might have been due to the presence of acidic air pollutants like $\mathrm{SO}_{2}$ and $\mathrm{NO}_{2}$ in the air that lowered the $\mathrm{pH}$ of the leaves [36]. Moreover significant variation in $\mathrm{pH}$ of leaves of both control and experimental sites with respect to species and seasons suggests that the other environmental conditions might have also influenced the $\mathrm{pH}$ variation in leaves besides the air pollutants.

Water content in plant leaves help maintain the physiological water balance in adverse environmental conditions. High relative water content of leaf favours transpiration rate and pollution resistance in plants [16]. In the present study, the relative water content of leaves of different tree species was $85.71 \%$ higher in experimental sites than in the control site, indicating that the tree species had responded well in the polluted areas. This was corroborated through significant positive correlation of relative water content with the APTI in the experimental sites and through significant variation with respect to species in the same sites by ANOVA test. High relative water content in leaves was also attributed to high moisture content in soil. Similar results were obtained by Das and Prasad [9].

In the present study, all the species were found to exhibit higher chlorophyll content in experimental sites than in the control site, which might have been due to low leaf $\mathrm{pH}$ in the experimental sites. This was corroborated by obtaining significant negative correlation between the leaf extract $\mathrm{pH}$ and the total chlorophyll content in the experimental sites. Higher values of chlorophyll in the experimental sites might have been the secondary reason of high ascorbic acid synthesis in the leaves of trees in the polluted areas. This is because of the fact that the total chlorophyll content in leaves of trees is intricately related to the ascorbic acid content, since the latter is mainly concentrated in chloroplasts [22]. However, the chlorophyll content did not show any significant correlation with the APTI in experimental sites, although it had significant correlation with the same in control site. So, it can be inferred that the two most important parameters that maintained or enhanced the defence mechanism in trees of the polluted areas are the ascorbic acid content and the relative water content of trees, and this inference is also drawn earlier through the statistical analysis. Most of the trees had their highest chlorophyll level during the monsoon (rainy season), followed by post-monsoon (winter) and the premonsoon (summer season). This might have been due to the fact that the deciduous trees were nearing their shedding season and the evergreen trees were nearing their leaf replacement season [22].

Further, in the present study the APTI value was increased in case of $61.71 \%$ of tree species in the experimental sites than in the control site. The species having high APTI value are supposed to have greater defence against air pollution. This corroborates the earlier reports that the trees exposed to polluted environment tend to increase their tolerance ability with high APTI values; can be used as a sink. Whereas the trees showing a decline in APTI value can be used as indicator [16, 32]. This idea can also be utilised to identify the trees suited for plantation.

When the tolerance grades were calculated for the trees in the control and experimental sites, large variation in grades were noted in different seasons. However, on an average grade count, $71.43 \%$ of the tree species showed the same or an improved tolerance grade in experimental sites as compared to the control site. Only $28.57 \%$ of the tree species showed deterioration in their tolerance grade in experimental sites as compared to the control site. Hence the species showing deterioration in the tolerance grade in experimental sites can be used as indicators against air pollution in the locality. The present findings are in line with the findings of Liu and Ding [22] and Das and Prasad [9].

The EPI of the trees in the present study was evaluated according to the obtained APTI value and the various biosocio-economic aspects. $23.81 \%$ of the total species were under poor to very poor performer category, and hence are unfit for plantation. Whereas, $33.33 \%$ species were found to be under the moderate to good category and 
$42.86 \%$ of the total species were found to be under very good to best performer category. The trees under very good to best performer category (i.e. F. religiosa, Madhuca indica, A. indica, A. heterophyllus, Mangifera indica, $F$. benghalensis and S. cumini) are deemed fit for plantation.

\section{Conclusion}

The combination of various parameters to assess the suitability of a tree species for plantation can be more reliable than assessment on the basis of one parameter. The present study revealed the following general conclusions:

(i) Air pollution have an impact on the biochemical synthesis and therefore on tolerance behaviour of trees.

(ii) Trees showing good tolerance can be schematically integrated to combat the pollution of an area.

(iii) Trees showing decline in tolerance grade can be used as bio-indicators for early detection of air pollution.

(iv) APTI and EPI in combination can be effective in identifying the suitable species for plantation.

Further, based on the APTI and EPI values of trees in the present study, it is concluded that species like F. religiosa, Madhuca indica, A. indica, A. heterophyllus, Mangifera indica, $F$. benghalensis and S. cumini can be used as a defence against the local air pollutants of Sambalpur town, while species like Z. jujuba, T. indica and T. peruviana can be effectively used as bio indicators to study the local pollution problems. This work will be highly helpful in formulating the greenery management strategy against rising air pollution issues of urban areas.

Acknowledgements The author (Chandan Sahu) highly acknowledge the Department of Science and Technology (DST), New Delhi, for providing the financial assistance through INSPIRE fellowship (Sanction Order No.: DST/INSPIRE Fellowship/2014/186) to carry out the research work. The authors also thankfully acknowledge the help rendered by Dr. A.K. Mohapatra, Professor of English, Sambalpur University for improving the language of the manuscript.

\section{Compliance with ethical standards}

Conflict of interest The authors declare that there is no conflict of interest.

\section{References}

1. Agbaire P, Esiefarienrhe E (2009) Air pollution tolerance indices (APTI) of some plants around Otorogun Gas Plant in Delta State, Nigeria. J Appl Sci Environ Manag 13:11-14
2. Anju PS, Jaya DS (2014) Air pollution tolerance index assessment of Quisqualis indica Linn in pollution prone areas of Thiruvananthapuram district in Kerala state, India. World J Environ Biosci 3(2):116-120

3. Arnon DI (1949) Copper enzymes in isolated chloroplasts. Polyphenoloxidase in Beta vulgaris. Plant Physiol 24:1-15

4. Babu GB, Parveen SN, Kumar KN, Reddy MS (2013) Evaluation of air pollution tolerance indices of plant species growing in the vicinity of cement industry and Yogi Vemana University campus, Indian. J Adv Chem Sci 2(1):16-20

5. Bora M, Joshi N (2014) A study on variation in biochemical aspects of different tree species with tolerance and performance index. The Bioscan 9(1):59-63

6. Chacko VJ (1965) A manual of sampling techniques for forest survey. Manager of Publications, Delhi, pp 1-110

7. Chaphekar SB, Boralkar DB, Shetey RP (1980) Effects of industrial pollution on plants. Final report of UGC sponsored project

8. Choudhury P, Banerjee D (2009) Biomonitoring of air quality in the industrial town of asansol using air pollution tolerance index approach. Res J Chem Environ 13(1):46-51

9. Das S, Prasad P (2010) Seasonal variation in air pollution tolerance indices and selection of plant species for industrial areas of Rourkela. Int J Environ Protect 30(12):978-988

10. Dohmen GP, Loppers A, Langebartels C (1990) Biochemical response of Norway Spruce towards 14 month exposure to ozone and acid mist, effect on amino acid, glutathione and polyamine titers. Environ Pollut 64:375-383

11. Escobedo FJ, Wagner JE, Nowak DJ (2008) Analyzing the cost effectiveness of Santiago, Chile's policy of using urban forest to improve air quality. J Environ Manag 86:148-157

12. Farooq M, Beg MU (1980) Effect of aqueous sulphur dioxide on the membrane permeability of common Indian tree leaves. New Bot 7:213-217

13. Gonzalez L, Gonzalez VM, Reigosa MJ (2001) Determination of relative water content. Handbook of plant ecophysiology techniques Kluwer. Academic Publishers. Dordrecht, The Netherlands, pp 207-212

14. Hoque MA, Banu MNA, Okuma E (2007) Exogenous proline and glycinebetaine increase $\mathrm{NaCl}$-induced ascorbate-glutathione cycle enzyme activities, and proline improves salt tolerance more than glycinebetaine in tobacco Bright Yellow-2 suspension - cultured cells. J Plant Physiol 164:1457-1468

15. Ifeanyi EC, Ogbonna CE (2012) Evaluation of air pollution tolerance index (APTI) of some selected ornamental shrubs in Enugu City, Nigeria. J Environ Sci Toxicol Food Technol 1(2):22-25

16. Jyothi SJ, Jaya DS (2010) Evaluation of air pollution tolerance index of selected plant species along roadsides in Thiruvanantapuram, Kerala. J Environ Biol 31:379-386

17. Keller T, Schwager H (1977) Air pollution and ascorbic acid. Eur J For Pathol 7:338-350

18. Kumar M (2013) Identification and evaluation of air pollution tolerance index of selected avenue tree species of urban Bangalore, India. Int J Emerg Technol Comput Appl Sci 13:388-390

19. Lakshmi PS, Sravanti KL, Srinivas N (2008) Air pollution tolerance index of various plant species growing in industrial areas. The Ecoscan 2(2):203-206

20. Lee SH, Ahsan N, Lee KW (2007) Simultaneous over expression of both CuZn superoxide dismutase and ascorbate peroxidise in transgenic tall fescue plants confers increased tolerance to a wide range of abiotic stresses. J Plant Physiol 164:1626-1638

21. Lima JS, Fernandes E, Fawcett W (2000) Mangifera indica and Phaseolar vulgaris in the bioindication of air pollution in Bahia, Brazil. Ecotoxicol Environ Saf 46:275-278

22. Liu YJ, Ding H (2008) Variation in air pollution tolerance index of plants near a steel factory: Implications for landscape_-plant 
species selection for industrial areas. Wseas Trans Environ Dev 4(1):24-32

23. Mahecha GS, Bamniya BR, Nair N, Saini D (2013) Air Pollution Tolerance Index of certain plant species-a study of Madri Industrial area, Udaipur (Raj.), India. Int J Innov Res Sci Eng Technol 2(12):7927-7929

24. Marimuthu K, Kalimuthu R, Ponraj K, Lavanya K, Magesh P, Jasbin SG (2014) Air Pollution tolerance index assessment of Yercaud road side plants. Int J Pharmaceut Sci Rev Res 26(2):177-181

25. Marimuthu K, Magesh $P$ (2014) Air pollution tolerance index induced by biochemical components in plants. Int J Pharm Pharm Sci 6(5):362-364

26. Meerabai G, Venkata RC, Rasheed M (2012) Effects of industrial pollutants on physiology of Cajanus cajan (L.) -Fabaceae. Int J Environ Sci 2(4):1889-1894

27. Mondal D, Gupta S, Datta JK (2011) Anticipated performance index of some tree species considered for green belt development in an urban area. Int Res J Plant Sci 2(4):99-106

28. Moore PD, Chapman SB (1986) Methods in plant ecology. Blackwell Scientific Publications, Oxford, pp 1-580

29. Noor MJ, Sultana S, Fatima S, Ahmad M, Zafar M, Sarfraz M, Balkhyour MA, Safi SZ, Ashraf MA (2014) Estimation of anticipated performance index and air pollution tolerance index and of vegetation around the marble industrial areas of Potwar region: bioindicators of plant pollution response. Environ Geochem Health 1-15

30. Panda LLS, Rai PK (2014) Study of air pollution tolerance index of some common road side plant species in an industrial (Rourkela) and non-industrial (Aizawl) area of India: an ecomanagement approach. Issues and Trends of Wildlife Conservation in Northeast India 86-95

31. Pasqualini S, Batini P, Ederli L (2001) Effects of short term ozone fumigation on tobacco plants: response of the scavenging system and expression of the glutathione reductase. Plant Cell Environ 24:245-252

32. Prajapati SK, Tripathi BD (2008) Anticipated performance index of some tree species considered for green belt development in and around an urban area: a case study of Varanasi city, India. J Environ Manag 88:1343-1349

33. Pradhan AA, Pattanayak SK, Bhadra AK, Ekka K (2016) Air pollution tolerance index of three species along national high way -6 between Ainthapali to Remed, Sambalpur District, Western Odisha, India. Biolife 4(1):111-120

34. Prasad DC (1992) Effects of air pollution. In: Misra SG (ed) Environmental pollution air, environmental pollution and hazards series. Venus Publishing House, New Delhi, pp 58-60

35. Ragragio EM, Padua AD, Datuin K, Sia-Su GLS, Sia-Su MLL (2014) Air POLLUTION TOLERANCE INDEX OF TREES IN selected areas in The Philippines. J Appl Phytotechnol Environ Sanit 3(1):17-22

36. Rai PK, Panda LLS, Chutia BM, Singh MM (2013) Comparative assessment of air pollution tolerance index (APTI) in the industrial (Rourkela) and non industrial (Aizawal) of India: an ecomanagement approach. Afr J Environ Sci Technol 7(10):944-948
37. Raza S, Murthy M (1988) Air pollution tolerance index of certain plants of Nacharam industrial area, Hyderabad. Indian J Bot 11:91-95

38. Sahu C, Sahu SK (2019) Ambient air quality and air pollution index of Sambalpur: a major town in Eastern India. Int J Environ Sci Technol 16(12):8217-8228

39. Sahu C, Sahu SK (2015) Air pollution tolerance index (APTI), anticipated performance index (API), carbon sequestration and dust collection potential of Indian tree species-A review. Int J Emerg Res Manag Technol 4(11):37-40

40. Sahu C, Basti S, Pradhan RP, Sahu SK (2016) Physicochemical properties of soil under different land use practices located near Bhawanipatna town in Odisha, India. Int J Environ Sci 6(6):941-953

41. Shannigrahi AS, Fukushim T, Sharma RC (2004) Anticipated air pollution tolerance of some plant species considered for green belt development in and around an industrial/urban area in india: an overview. Int J Environ Stud 61(2):125-137

42. Sharma M, Panwar N, Arora P, Luhach J, Chaudhry S (2013) Analysis of biological factors for determination of air pollution tolerance index of selected plants in Yamuna Nagar, India. J Environ Biol 34:509-514

43. Singh S, Rao D (1983) Evaluation of plants for their tolerance to air pollution. In: Proceedings of the symposium on air pollution control. 281-224

44. Snedecor GW, Cochran WG (1980) Statistical methods, 7th edn. lowa State University Press, Ames, lowa

45. Steubing L, Fangmier A, Both $\mathrm{R}$ (1989) Effect of $\mathrm{SO}_{2}, \mathrm{NO}_{2}$ and $\mathrm{O}_{3}$ on population development and morphological and physiological parameters of native herb layer species in a beech forest. Environ Pollut 58:281-302

46. Thakar B, Mishra PC (2010) Dust collection potential and air pollution tolerance index of tree vegetation around Vedanta Aluminium Limited, Jharsuguda. The Bioscan 3:603-612

47. Thambavani DS, Maheswari J (2012) Evaluation of anticipated performance index of certain tree species in Virudhunagar, India. IPCSIT 38:1-6

48. Trivedy RK, Goel PK (1995) An introduction to air pollution. Technoscience Publication, Jaipur (India), p 262

49. Varshney CK (1985) Role of plant in indicating, monitoring and mitigating air pollution. In: Air pollution and plants: a state of the art report (Eds. G.V. Subrahmanium, D.N. Rao, C.K. Varshney and D.K. Viswas.). Ministry of Environment and Forest, New Delhi 146-170

50. Yannawar VB, Bhosle AB (2014) Air Pollution Tolerance Index of various plant species around Nanded city, Maharashtra, India. J Appl Phytotechnol Environ Sanit 3(1):23-28

Publisher's Note Springer Nature remains neutral with regard to jurisdictional claims in published maps and institutional affiliations. 